\title{
MANAGING For VAlUE: DEVELOPING A \\ PERForMANCE MEASUREMENT SYSTEM INTEGRATING ECONOMIC VALUE ADDED AND THE BALANCED SCORECARD IN STRATEgiC PlaNNING
}

\author{
Harold D. Fletcher, Ph.D. \\ Darlene Brannigan Smith, Ph.D. \\ Loyola College in Maryland \\ Timonium, MD
}

\begin{abstract}
Economic value added (EVA) systems and the balanced scorecard (BSC) have generated a tremendous interest in corporate America recently as approaches to performance management. Implementation of these methodologies has not proven to be easy. This paper introduces the analytical hierarchy process and shows how this methodology addresses the limitations of EVA and BSC by integrating them into one comprehensive system. A case study is used to illustrate this methodology.
\end{abstract}

\section{Introduction}

Managing for value has become the mantra of today's executives as the reality of today's competitive environments force businesses to focus on improving profitability. Firms, both large and small, are implementing value-based measures using measures such as Economic Value Added (EVA). All too often, however, these initiatives are interpreted merely as an advance in metrics and measurement and not a tool for strategy development. This narrow interpretation and use suggests little fundamental change in the behavior of the many people responsible for the decisions and actions that create long-term value and has brought only mediocre results to some firms. To improve the implementation of value based management (VBM), firms need to move beyond narrow metrics to the utilization of EVA as a strategic decision tool. It must be linked to broad process reforms including the identification of value drivers, the integration of budgeting with strategic planning, and development of a comprehensive performance measurement system. This is the objective of our paper.

We focus on the development of a complementary system of managerial metrics linking the EVA system to the Balanced Scorecard (BSC) using analytical hierarchy processing (AHP). The importance of managing for value is discussed and potential limitations identified. The Balanced Scorecard as a vehicle for identifying value drivers and drilling down into the operations of the firm is presented. Then, these two complementary frameworks are combined, using the AHP methodology, to develop a comprehensive measurement system for 
assessing the overall performance of the organization. A case study is used to illustrate this methodology.

\section{Economic Value Added}

A paramount objective of management should be the creation of value for the firm. Thus, it is essential in strategic planning to manage the firm's resources with an objective of increasing the firm's market value (Hawawini and Viallet 2002; Eccles and Pyburn 1992). From an EVA perspective, the ultimate success of a firm is not measured only by its capacity to grow its sales, produce profits, or generate cash from its operations, but whether the firm's activities are creating value for its owners (Ehrbar 1998). According to economic theory, a firm is creating value if the net present value of all its investments is positive. Quite simply, EVA is a measure that enables managers to see whether they are earning an appropriate return on the capital under their control. It is a measure of profit less the cost of capital employed (EVA calculations are provided in Exhibit 1) and is the one measure that properly accounts for all the complex trade-offs, often between the income statement and balance sheet, in creating value (Pettit 2000).

\section{Exhibit 1 \\ EVA Equations}



The EVA metric is not only a measure of financial performance but should serve as the centerpiece of a strategy development and implementation process. Putting value based management into practice, however, has been found to be more complicated than some of its proponents suggest. Haspeslagh, Nada and Boulos (2001) found a number of characteristics associated with the successful implementation of value based management (VBM). Successful VBM companies keep the technical accounting aspects of EVA simple, making very few changes to their accounting practices. They invest time and effort in identifying and assessing the operational factors, or value drivers, that have the greatest influence on the creation of economic profit. These firms integrate their entire system into a single process including the continual monitoring and alignment of compensation to performance. And, perhaps equally important, successful firms 
institute broad based VBM training so that all frontline employees and managers understand the concept of value creation and their role in the process.

EVA is not without its limitations. A major limitation is its over-reliance on historical, financial measures such as profit margin, asset turnover, cost of money, and level of capital invested in the firm. Recent research has shown that these lagging, financially oriented measures are not necessarily indicative of future performance. In many industries, in a range of business sectors, leading drivers (i.e., forward-looking drivers) have shown to more important in predicting future EVA than current EVA, but they are not directly included in most EVA systems (Ittner, Larcker and Rajan 1997; Epstein and Manzoni 1998; Banker, Potter, Srinivasan 2000). These leading drivers are often nonfinancial in nature and encompass such factors as product innovation, customer satisfaction and loyalty, employee productivity, product quality, brand equity, etc. (Lynch and Cross 1995). The importance of focusing on these value drivers is twofold. Not only do they focus the activities of frontline employees on value creation, but also they tend to push the management team to develop its strategies with much greater clarity. The question becomes how to integrate financial and non-financial drivers (i.e., leading and lagging indicators) into the planning and valuation process.

\section{The Balanced Scorecard}

The Balanced Scorecard (BSC) is a performance management tool that has been used to foster a more integrated perspective of the organization and the valuation process. Developed by Kaplan and Norton (1992), it is based on the concept that managers must manage and evaluate their business from at least four major perspectives: customers, internal business process, innovation and learning, and financial. These four perspectives encourage management to develop an integrated strategy around the following four questions:

1. How do customers view the firm? (The customer perspective is measured in part by indicators of customer satisfaction, on-time delivery, share of key accounts' purchases, ranking by key accounts.)

2. What business processes must the firm improve and exceed at? (The internal business perspective is measured in part by indicators such as cycle time, unit cost, yield, and quality.)

3. Can the firm continue to learn and innovate? (The innovation and learning perspective is measured in part by indicators such as percent of sales from new products, development time for the next generation of products, quantity and quality of employee suggestions, and employee skill development.)

4. How does the firm appear to its shareholders? (The financial perspective is measured in part by such indicators as cash flow, return on equity, market share.)

The scorecard takes a balanced look at the organization because it focuses on (1) leading and lagging drivers of performance, (2) financial and non-fi- 
nancial measurements, and (3) quantitative as well as qualitative measures of performance. If properly implemented, it is an excellent management framework to help managers track the many factors that influence performance. The ability of the BSC to provide this view depends upon the construction of a set of performance measures that track how successfully a firm is carrying out its strategies, objectives, and overall mission.

Financial performance, whether measured by EVA or some other metric, should always be the end goal, but the balance scorecard reminds us that financial measures are lagging indicators. They tell us how the company performed after the fact (Young \& O'Byrne 2001, Fisher 1992). Delivering ever increasing amounts of EVA requires that we understand the leading indicators of value; the measures that signal value-creation or value-destroying behavior before the results over show up in EVA. A limitation of the BSC, however, is that it lacks a single focus for accountability. What the BSC does not do but what management needs is one comprehensive index to summarize the interaction between these leading and lagging measures of performance. While the BSC may tell us what measures to look at, it does not tell us how to look at them or their relative importance.

\section{Integrating EVA and the Balanced Scorecard}

Although the balanced scorecard was not explicitly created with EVA in mind, the framework has proven to be highly complementary to it (Young \& O'Byrne 2001). In practice, EVA and BSC must be viewed as an integrated system representing a continuum going from leading indicators such as employee satisfaction and morale, quality, and customer satisfaction to lagging indicators such as EVA. The strength of EVA is that it focuses the firm on its fundamental mission of value creation. The strength of BSC is that it focuses management attention on the key causal pathways to value creation.

All too often, firms invest in decision support tools such as the balanced scorecard and the EVA but do not use them effectively, mainly because managers have difficulty in relating them directly to ongoing operations. Exhibit 2 organizes performance indicators in a causal chain. This strategic map shows that indicators can be thought of as a continuum. Customer satisfaction is a leading indicator of EVA, but it may also be a lagging indicator of on-time delivery. In other words, better on-time delivery improves customer satisfaction, which leads to higher sales and the speedier collection of receivables, which in turn lead to higher EVA. While on-time delivery is a leading indicator of customer satisfaction, it may also be lagging indicator of production cycle time and the quality of both the manufacturing process and the product themselves. Process and product quality, rework rates, and cycle times are, in turn, lagging indicators of employee skills and morale. The balanced scorecard focuses management attention on these causal relationships leading to higher EVA. 


\section{Exhibit 2 \\ Causal Chain}

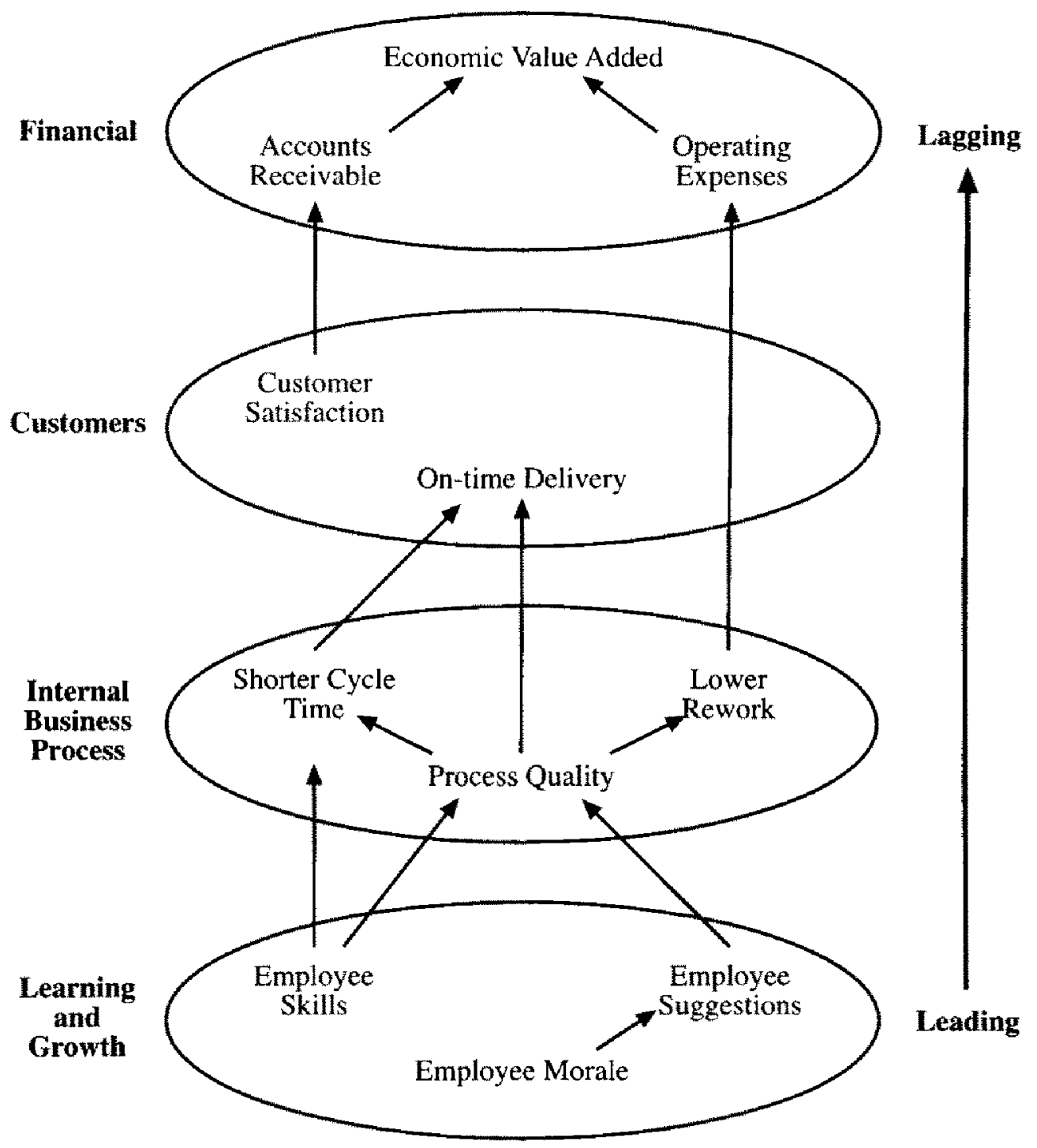

The key to integrating these two systems is quantifying the relative importance of the firm's leading and lagging indicators and meshing them into one comprehensive performance index. We propose employing the multi-criteria decision-making technique known as the analytical hierarchy process (AHP) as the tool to facilitate this linkage, to develop an integrated performance index, and to monitor its implementation. AHP has been increasingly used to link qualitative and quantitative measures in an integrating framework (Liberatore et al 1997, Pineno 2000). It has been applied to business problems and is particularly useful for allocating resources, planning, analyzing the impact of policy and resolving conflicts (Saaty 1996). 


\section{The AHP-Based Valuation Framework}

The AHP developed by Saaty is a proven method for structuring and analyzing complex, multilevel decision-making problems (Saaty 1996). Basically, the AHP is a method of breaking down a complex situation into its component parts; arranging these parts (or variables) into a hierarchic order; assigning numeric values to subjective judgments on the relative importance of each variable; and synthesizing the judgments to determine which variables have the highest priority and should be acted up to influence the outcome of the situation. AHP incorporates judgments and personal values in a logical way. It depends on imagination, intuition and knowledge to structure the hierarchy of a problem and on logic, intuition and experience to provide judgments about the relative rankings.

An important feature of AHP is that it provides an effective structure for group decision making by imposing a discipline for the group's thought processes. This feature is ideal for strategic planning because ideas and judgments can be questioned and strengthened or weakened by evidence that other people present. In addition, the necessity of assigning a numeric value to each variable of the problem helps managers to maintain strategic patterns and to reach a conclusion. The consensual nature of group decision-making improves the consistency of managers' judgments and enhances the validity and reliability of the AHP as a decision-making tool.

In the context of strategic planning, AHP begins by structuring a strategic plan into a hierarchy (Step 1). The highest level is the overall objective (e.g., enhancing EVA). The secondary level encompasses the strategic alternatives / options for the firm. The tertiary level identifies the value drivers and their associated metrics (i.e., frontline activities of the firm that will contribute positively to the overall objective of increasing value). After developing the hierarchy, the next step is for the planning team to judge the relative weight or importance of each of these value drivers to the firm's ability to succeed in achieving its EVA objective (Step 2). The relative weights of the performance metrics are then used to create an overall index of performance for the firm, which collectively uses the key performance measures to monitor and assess performance (Step 3).

As with any strategic planning process, those responsible for implementing this methodology should be prepared to deal with such problems as inequality of power and expertise among members, unequal desire to express preferences, frequent change of expressed preferences, and the unwillingness of some to reveal their preferences or the true strength of their preferences (Saaty 1996). Most of the problems in applying the AHP occur in the priority-setting stage, particularly when the process is being used for the first time. It is important to recognize that consensus is not essential at the lower levels of the hierarchy, but it is needed at the higher levels, where the priorities drive the rest of the hierarchy. In conducting planning sessions, the facilitator should be concerned about these problems but through careful preparation, good examples, and sensitivity to group dynamics, these problems can be overcome. 
The advantages and disadvantages of the AHP have been extensively debated. A series of articles in Management Science examines the theoretical strengths and weaknesses of AHP (Dyer 1990A, Dyer 1990B, Harker and Vargas 1990, Saaty 1990, Winkler 1990). Recent developments in the AHP literature have addressed and effective resolved the principal objectives. This research illustrates that AHP has been widely and successfully applied in a variety of decision-making environments (Wasil and Golden 1991; Vargas and Zahedi 1993; Liberatore et al 1997).

\section{Lavas: A Case Study'}

To illustrate the integration of EVA and BSC using AHP, we worked with an east coast food distribution firm developing its strategic plan, monitoring its implementation and assessing its performance. Lavas Foods Corporation (Lavas) is a privately-held company that enjoys a solid reputation in its industry for providing specialized distribution of over 7,200 restaurant products. It has generally been considered one of the industry leaders in its market segments. The organization views itself as having several distinctive characteristics. It is a small, lean organization with few middle management personnel, allowing easy access to top decision-makers. The company has many long-term employees and its labor force is entirely non-union. It has a family oriented corporate culture with second and third generations of the family owning and managing the business. Senior executives maintain tight controls on the work product through hands-on contact and are the individuals primarily responsible for strategic planning. The strategic planning committee consists of eight members: the Chairman of the Board, President, Chief Financial Officer, Director of Information Systems, and the Vice Presidents of Distribution, Marketing, Operations and Purchasing.

In early 2000 , Lavas found its sales growth had been stunted due to an increase in competition from large, well-financed national distribution companies, increased merger and acquisition activity, and slower growth in some market segments. While Lavas had always enjoyed a fine reputation, it had only recently achieved renewed profitability. Lavas's strategic plan articulated that its mission was to "Maximize stakeholder and stockholder value by being the industry leader in niche markets with a goal of achieving an EVA of $\$ 1.2$ million". To meet this goal, management determined that it had to aggressively market to its existing customers, cultivate new customers, develop new products, improve its efficiency and productivity, and increase profitability in order to attract new sources of financing. This latter initiative was particularly important given Lavas was highly leveraged because of substantial recent investment in its production and distribution facilities.

Lavas has utilized a value based management approach for several years but had difficulty aligning the frontline activities of the firm to enhance profitability and value creation. In the previous year it began implementing a balanced 
scorecard management system to augment the development of key performance measures in the key areas of finance, customer, internal processes, and innovation / learning. A difficulty arose, however, because the scorecard was not directly integrated in the value based management system, the budgeting process and the compensation structure. The current planning cycle sought to integrate the entire strategic planning system into a single process driven by value based management.

Lavas' current strategic plan identified four primary objectives: Sales Growth, Profitability, Customer Satisfaction and Retention, and Employee Satisfaction and Retention. Its balanced scorecard framework is shown in Exhibit 3. The AHP framework was used by management to prioritize the relative importance of each of these strategic drivers and develop an index to monitor overall organizational performance. A discussion of this process and its use by Lavas follows.

\section{Step 1 - Construct AHP Linking The Firm's EVA Mission And Objectives To The Balanced Scorecard}

Expert Choice 2000 is a user-friendly AHP software package that enables the user to quickly and easily structure hierarchies, enter all necessary judgments, and automatically compute the alternative and criteria weights. Using standard AHP nomenclature, an AHP model must have an explicit goal, and in the case of Lavas Foods it was to achieve an EVA target of $\$ 1.2$ million. A hierarchy is constructed to link the goal to alternatives. Alternatives can be viewed as strategic options for achieving the goal. The criteria are then identified. They represent the measures used to access the performance of Lavas' financial and non-financial drivers of value. This hierarchy is illustrated in Exhibit 3 and is translated as follows:

1. Goal: Maximize stakeholder and shareholder value by achieving an EVA of $\$ 1.2$ million.

2. Strategic Alternatives / Objectives: Each of Lavas' strategic objectives are explicitly identified: (1) Grow sales, (2) Enhance profitability, (3) Satisfy and retain customers and (4) Satisfy and retain employees.

3. Criteria: Key performance measures are presented under each of their BSC respective perspectives (i.e., finance, customer, internal business, innovation / learning). Identifying each measure to its underlying BSC perspective is one way of ensuring that each perspective has been taken into consideration in the strategy development and performance management process.

\section{Step 2 - Use The AHP To Determine The "Weights" Or Relative Impor- tance Of The Individual Key Performance Measures}

AHP models use pairwise comparisons to assess the relative importance of each of the strategic objectives and the importance of each of the criteria (i.e., the BSC performance measures) in meeting the EVA goal and each strategic objective. These comparisons are entered using one of several modes, including 


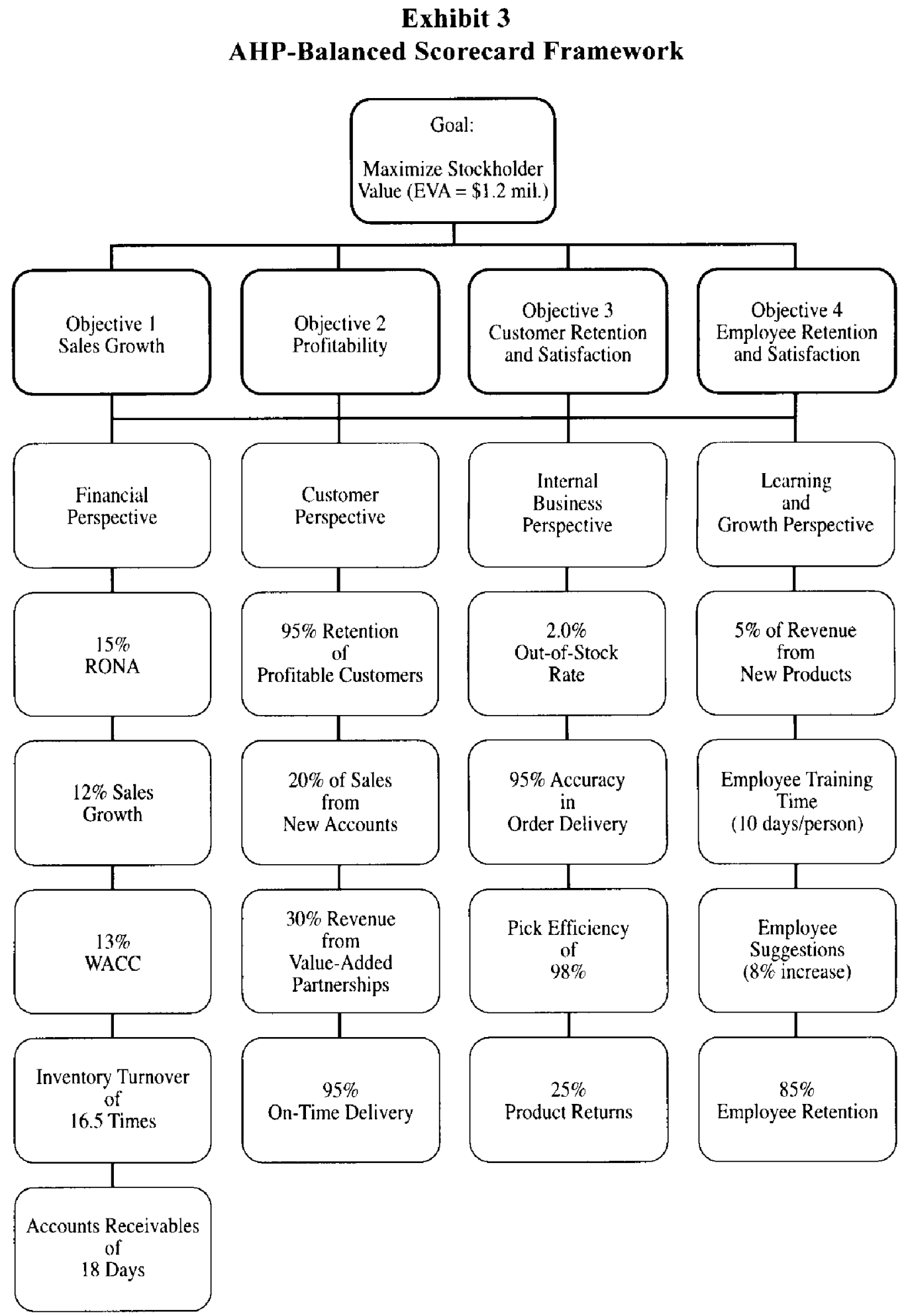

verbal, numerical and graphical approaches. The results are synthesized. Expert Choice automatically computes the weights and a measure of the consistency of judgments. 
Lavas' management team met over the course of several weeks to debate the relative priorities of these value drivers. Once a consensus was obtained, the management team consulted its outside Board of Advisors to validate their judgments. This iterative process led to subsequent refining of the priorities. Ultimately, management's pairwise comparisons yielded differential weights for the four strategic objectives as well as the four components of the balanced scorecard.

The weights shown below are based on management's evaluation of the significance of the performance measure to Lavas' unique competitive environment. As a small firm, competing in a mature market against large national competitors, customer and sales oriented objectives and measures were higher priorities than financial measures. It was important to grow sales and to retention its customers in order to enhance its ability to capture competitor's customers.

\section{Lavas' Relative Priorities}

\section{Balanced Scorecard Perspectives Strategic Objectives}

$31.7 \%$ Customer Perspective

$27.1 \%$ Internal Business Perspective

$26.2 \%$ Financial Perspective

$15.0 \%$ Innovation \& Learning
$29.8 \%$ Sales Growth

$29.7 \%$ Customer Satis. / Retention $25.6 \%$ Profitability

14.9\% Employee Satis. /Retention

Exhibit 4 summarizes the relative weights of the 17 key performance measures as calculated by the AHP model. These weights relate the relative importance of each performance measure to Lavas' efforts to meets its overall goal of achieving an EVA of $\$ 1,2$ million. For example, RONA has a relative weight or importance of $5.9 \%$ (among all the performance measures), sales growth has a weight of $6.3 \%$, WACC has a weight of $4.6 \%$, and so on. Note that the relative weights of the full set sum to $100 \%$. The baseline or targeted values in Exhibit 4 provide an index score that can be used to track the firm's progress.

\section{Step 3 - Use Key Performance Measures To Construct An Index To Moni- tor Overall Firm Performance}

Lavas then tracked performance on each measure and monitored the firm's overall performance using the index. By individually tracking each performance measure from quarter to quarter, and quantifying the relative effect of each change, we can construct an index to monitor the firm's progress toward its strategic targets. Weights below the targeted AHP measure indicate problem areas; weights equal to or greater than the targeted AHP measure indicate that Lavas met or exceeded its targeted goal.

Exhibits 5 through 8 compare each quarter's performance to target using the AHP-driven performance index. "Percent of target" for each measured in 
Exhibit 4

Performance Measurement Index

\begin{tabular}{lcc}
\hline Firm Performance Measure & Target & AHP Weight \\
\hline Financial Perspective & & \\
1. RONA & $15.0 \%$ & $5.9 \%$ \\
2. Sales Growth & $12.0 \%$ & $6.3 \%$ \\
3. WACC & $13.0 \%$ & $4.6 \%$ \\
4. Inventory Turnover & 16.5 & $4.8 \%$ \\
5. Accounts Receivable Days & 18 & $4.6 \%$ \\
Customer Perspective & & \\
6. Customer Retention Rate & $95.0 \%$ & $8.2 \%$ \\
7. Sales from New Accounts & $20.0 \%$ & $7.3 \%$ \\
8. Revenue from Value-Added Partnerships & $30.0 \%$ & $6.4 \%$ \\
9. On-time Delivery & $95.0 \%$ & $9.8 \%$ \\
Internal Business Perspective & & \\
10. Out-of-Stock (\%) & $2.0 \%$ & $5.9 \%$ \\
11. Accuracy in Delivery Order (\%) & $95.0 \%$ & $7.1 \%$ \\
12. Pick Efficiency Time & $98.0 \%$ & $3.9 \%$ \\
13. Product Returns (\%) & $2.0 \%$ & $5.4 \%$ \\
14. \% of Revenue from New Products & $5.0 \%$ & $4.8 \%$ \\
Innovation and Learning Perspective & & \\
15. Employee Training Days & 10.0 & $5.8 \%$ \\
16. Employee Suggestions (\% Increase) & $8.0 \%$ & $4.3 \%$ \\
17. Employee Retention & $85.0 \%$ & $4.9 \%$ \\
Baseline Performance Index & & $100.0 \%$ \\
\hline
\end{tabular}

calculated by dividing the quarter results by the target times 100 . For example in quarter one RONA was $14.5 \%$ and the goal was $15.0 \%$. This results in an index of $96.7 \%(14.5 / 15.0 \times 100)$. This "Percent of Target" is then multiplied by the measure's AHP weight to calculate its relative value in the "Performance Index". Thus, the first quarter RONA rate had a performance index of $5.7 \%$ $(96.7 \% \times 5.9 \%)^{2}$.

As shown in Exhibit 5, Quarter 1 yielded a performance index of $94.7 \%$ suggesting that Lavas fell short of its target. It met 7 of its BSC targets (WACC, Customer Retention Rate, Revenue from Value-Added Partnerships, On-Time Delivery, Out-of-Stock Percent, Accuracy in Delivery Order / Pick Rate, and Employee Training Days). It fell short on the other 10 targets. "Sales Growth" was only $83 \%$ of target, achieving a $10 \%$ growth rate instead of its targeted $12 \%$. "Product Returns" had a target of $2 \%$ but $3 \%$ of products were actually returned exceeding its target by $50 \%$. Revenue from New Products grew by $4.2 \%$, short of its target of $5.0 \%$. Corrective actions were taken early in quarter two. For example, a telephone survey of key accounts was conducted to assess reasons for product returns. Based on these findings, an enhanced monitoring system was implemented which resulted in Lavas exceeding its second quarter 


\section{Exhibit 5}

Quarter 1 Performance Compared to Targeted Performance

\begin{tabular}{|c|c|c|c|c|}
\hline Firm Perfomance Measure & $\begin{array}{c}\text { AHP } \\
\text { Target } \\
\text { Weight }\end{array}$ & $\begin{array}{l}\text { Qtr } 1 \\
\text { Data }\end{array}$ & $\begin{array}{c}\text { Percent } \\
\text { of } \\
\text { Target }\end{array}$ & $\begin{array}{l}\text { Perf. } \\
\text { Index }\end{array}$ \\
\hline 1. RONA & $5.9 \%$ & $14.5 \%$ & $96.7 \%$ & $5.7 \%$ \\
\hline 2. Sales Growth & $6.3 \%$ & $10.0 \%$ & $83.3 \%$ & $5.3 \%$ \\
\hline 3. WACC & $4.6 \%$ & $13.0 \%$ & $100.0 \%$ & $4.6 \%$ \\
\hline 4. Inventory Turnover & $4.8 \%$ & 15.5 & $93.9 \%$ & $4.5 \%$ \\
\hline 5. Accounts Receivable Days & $4.6 \%$ & 20.0 & $88.9 \%$ & $4.1 \%$ \\
\hline 6. Customer Retention Rate & $8.2 \%$ & $96.0 \%$ & $101.1 \%$ & $8.3 \%$ \\
\hline 7. Sales from New Accounts & $7.3 \%$ & $18.0 \%$ & $90.0 \%$ & $6.6 \%$ \\
\hline 8. Revenue from Value-Added Partnerships & $6.4 \%$ & $31.0 \%$ & $103.3 \%$ & $6.6 \%$ \\
\hline 9. On-time Delivery & $9.8 \%$ & $96.0 \%$ & $101.1 \%$ & $9.9 \%$ \\
\hline 10. Out-of-Stock $(\%)$ & $5.9 \%$ & $1.5 \%$ & $125.0 \%$ & $7.4 \%$ \\
\hline 11. Accuracy in Delivery Order $(\%)$ & $7.1 \%$ & $96.0 \%$ & $101.1 \%$ & $7.2 \%$ \\
\hline 12. Pick Efficiency Time & $3.9 \%$ & $97.0 \%$ & $99.0 \%$ & $3.9 \%$ \\
\hline 13. Product Returns $(\%)$ & $5.4 \%$ & $3.0 \%$ & $50.0 \%$ & $2.7 \%$ \\
\hline 14. $\%$ of Revenue from New Products & $4.8 \%$ & $4.2 \%$ & $84.0 \%$ & $4.0 \%$ \\
\hline 15. Employee Training Days & $5.8 \%$ & $10.0 \%$ & $100.0 \%$ & $5.8 \%$ \\
\hline 16. Employee Suggestions (\% Increase) & $4.3 \%$ & $7.0 \%$ & $87.5 \%$ & $3.8 \%$ \\
\hline 17. Employee Retention & $4.9 \%$ & $78.0 \%$ & $91.8 \%$ & $4.5 \%$ \\
\hline Performance Index $(\%)$ & $100.0 \%$ & & & $94.7 \%$ \\
\hline
\end{tabular}

target. To increase sales from new products, the sales team doubled the number of "taste testings" to stimulate interest in new products, yielding significantly higher second quarter results of $98 \%$ of target.

While these corrective actions improved some key performance areas as shown in Exhibit 6, overall results in Quarter 2 were disappointing $(91.5 \%$ performance index) because of slippage in other areas. Management was particularly concerned about worsening sales growth ( $75 \%$ of target), an increase in the number of out-of-stock items, and the decline in employee development (training and suggestions). A company-wide meeting, more like a pep rally, was held to help motivate people and to improve employee's involvement in the day-to-day operations. The meeting yielded a number of implemental ideas to reduce out-of-stock conditions. The Vice-President of Sales met with each salesperson to better focus sales efforts. The results of these corrective actions began to appear in Quarter 3 (Exhibit 7) with overall performance increasing from $91.5 \%$ to $94.1 \%$ of target.

While still short of the target, the evidence indicated a rebound. Out-ofStocks were reduced and sales increased, including sales from new accounts. One significant problem area, on-time delivery representing $9.8 \%$ of our target index, continued to plague Lavas. To correct this deficiency, some routes were re-drawn and two new drivers were added. By Quarter 4 (Exhibit 8) the cor- 


\section{Exhibit 6 \\ Quarter 2 Performance Compared to Targeted Performance}

\begin{tabular}{|c|c|c|c|c|}
\hline Firm Perfomance Measure & $\begin{array}{c}\text { AHP } \\
\text { Target } \\
\text { Weight }\end{array}$ & $\begin{array}{l}\text { Qtr } 2 \\
\text { Data }\end{array}$ & $\begin{array}{c}\text { Percent } \\
\text { of } \\
\text { Target }\end{array}$ & $\begin{array}{c}\text { Perf. } \\
\text { Index }\end{array}$ \\
\hline 1. RONA & $5.9 \%$ & $15.5 \%$ & $103.3 \%$ & $6.1 \%$ \\
\hline 2. Sales Growth & $6.3 \%$ & $9.0 \%$ & $75.0 \%$ & $4.7 \%$ \\
\hline 3. WACC & $4.6 \%$ & $13.0 \%$ & $100.0 \%$ & $4.6 \%$ \\
\hline 4. Inventory Turnover & $4.8 \%$ & 17.0 & $103.0 \%$ & $4.9 \%$ \\
\hline 5. Accounts Receivable Days & $4.6 \%$ & 17.0 & $105.6 \%$ & $4.9 \%$ \\
\hline 6. Customer Retention Rate & $8.2 \%$ & $93.0 \%$ & $97.9 \%$ & $8.0 \%$ \\
\hline 7. Sales from New Accounts & $7.3 \%$ & $19.0 \%$ & $95.0 \%$ & $6.9 \%$ \\
\hline 8. Revenue from Value-Added Partnerships & $6.4 \%$ & $28.0 \%$ & $93.3 \%$ & $6.0 \%$ \\
\hline 9. On-time Delivery & $9.8 \%$ & $93.0 \%$ & $97.9 \%$ & $9.6 \%$ \\
\hline 10. Out-of-Stock $(\%)$ & $5.9 \%$ & $3.0 \%$ & $50.0 \%$ & $3.0 \%$ \\
\hline 11. Accuracy in Delivery Order $(\%)$ & $7.1 \%$ & $93.0 \%$ & $97.9 \%$ & $7.0 \%$ \\
\hline 12. Pick Efficiency Time & $3.9 \%$ & $96.0 \%$ & $98.0 \%$ & $3.8 \%$ \\
\hline 13. Product Returns (\%) & $5.4 \%$ & $1.8 \%$ & $110.0 \%$ & $5.9 \%$ \\
\hline 14. $\%$ of Revenue from New Products & $4.8 \%$ & $4.9 \%$ & $98.0 \%$ & $4.7 \%$ \\
\hline 15. Employee Training Days & $5.8 \%$ & 6.0 & $60.0 \%$ & $3.5 \%$ \\
\hline 16. Employee Suggestions (\% Increase) & $4.3 \%$ & $6.0 \%$ & $75.0 \%$ & $3.2 \%$ \\
\hline 17. Employee Retention & $4.9 \%$ & $81.0 \%$ & $95.3 \%$ & $4.7 \%$ \\
\hline Performance Index (\%) & $100.0 \%$ & & & $91.5 \%$ \\
\hline
\end{tabular}

rective actions previously instituted begin to take hold. A performance index of 97.8\% was achieved. It ended the year with an EVA of $\$ 1.1$ million.

The Lavas case study illustrates how scorecard drivers can be integrated into a value based management system using the analytical hierarchy process to develop an integrated performance measurement system. This approach enabled Lavas to better develop strategy and monitor its implementation and performance. While many of the decisions and subsequent results reported in this paper are short term in nature, this should not diminish the benefits of this methodology, which for Lavas were four-fold. Lavas was able to link daily operational performance to goals and systematically measure performance over time. Management intervened only when performance drivers appeared to go off track or needed to be revised in light of changes in the marketplace. They reduced the propensity to set budgets and short-term activities that were contradictory to the long-term strategic plan. Their frontline employees had a shared understanding of what created success in various parts of the business in both the short and long term and who in the organization could affect those drivers. In a lean organization with many long-term employees, this shared philosophy is critical to sustained success. The total process (managing for value, using a scorecard approach in developing strategy and identifying metrics, continuous monitoring) encouraged top management to listen more 
Exhibit 7

Quarter 3 Performance Compared to Targeted Performance

\begin{tabular}{|c|c|c|c|c|}
\hline Firm Perfomance Measure & $\begin{array}{c}\text { AHP } \\
\text { Target } \\
\text { Weight }\end{array}$ & $\begin{array}{l}\text { Qtr } 3 \\
\text { Data }\end{array}$ & $\begin{array}{c}\text { Percent } \\
\text { of } \\
\text { Target }\end{array}$ & $\begin{array}{c}\text { Perf. } \\
\text { Index }\end{array}$ \\
\hline 1. RONA & $5.9 \%$ & $14.0 \%$ & $93.3 \%$ & $5.5 \%$ \\
\hline 2. Sales Growth & $6.3 \%$ & $12.0 \%$ & $100.0 \%$ & $6.3 \%$ \\
\hline 3. WACC & $4.6 \%$ & $13.0 \%$ & $100.0 \%$ & $4.6 \%$ \\
\hline 4. Inventory Turnover & $4.8 \%$ & 14.0 & $84.8 \%$ & $4.1 \%$ \\
\hline 5. Accounts Receivable Days & $4.6 \%$ & 21.0 & $83.3 \%$ & $3.8 \%$ \\
\hline 6. Customer Retention Rate & $8.2 \%$ & $98.0 \%$ & $103.2 \%$ & $8.5 \%$ \\
\hline 7. Sales from New Accounts & $7.3 \%$ & $21.0 \%$ & $105.0 \%$ & $7.7 \%$ \\
\hline 8. Revenue from Value-Added Partnerships & $6.4 \%$ & $27.0 \%$ & $90.0 \%$ & $5.8 \%$ \\
\hline 9. On-time Delivery & $9.8 \%$ & $92.0 \%$ & $96.8 \%$ & $9.5 \%$ \\
\hline 10. Out-of-Stock $(\%)$ & $5.9 \%$ & $2.0 \%$ & $100.0 \%$ & $5.9 \%$ \\
\hline 11. Accuracy in Delivery Order $(\%)$ & $7.1 \%$ & $96.0 \%$ & $101.1 \%$ & $7.2 \%$ \\
\hline 12. Pick Efficiency Time & $3.9 \%$ & $96.0 \%$ & $98.0 \%$ & $3.8 \%$ \\
\hline 13. Product Returns (\%) & $5.4 \%$ & $2.1 \%$ & $95.0 \%$ & $5.1 \%$ \\
\hline 14. \% of Revenue from New Products & $4.8 \%$ & $5.5 \%$ & $110.0 \%$ & $5.3 \%$ \\
\hline 15. Employee Training Days & $5.8 \%$ & 7.0 & $70.0 \%$ & $4.1 \%$ \\
\hline 16. Employee Suggestions (\% Increase) & $4.3 \%$ & $4.0 \%$ & $50.0 \%$ & $2.2 \%$ \\
\hline 17. Employee Retention & $4.9 \%$ & $85.0 \%$ & $100.0 \%$ & $4.9 \%$ \\
\hline Performance Index (\%) & $100.0 \%$ & & & $94.1 \%$ \\
\hline
\end{tabular}

effectively to their employees and to share information with them. This was a critical factor in its success.

\section{Conclusion}

If it is true that behavior is determined by what is measured and rewarded, traditional financial measures of performance no longer reflect the realities of today's environment where innovation, quality and a customer focus are the rules of the game. Long-term success requires a performance assessment framework that monitors and reports on the value of efforts across the entire business. We have presented a framework for improving the implementation of value based management by using the Balanced Scorecard to identify value drivers and developing a comprehensive performance measurement system quantitatively linking them to the firm's objectives of maximizing shareholder value.

EVA and the BSC are two approaches to performance management. The limitation of EVA is its lack of leading indicators. The limitation of the BSC is its lack of a well-defined measurement system. We have presented a framework to address these limitations. The increased accuracy and timeliness provided by an AHP valuation framework enhances the ability of the firm to monitor strategy implementation on a real-time basis. 


\section{Exhibit 8}

Quarter 4 Performance Compared to Targeted Performance

\begin{tabular}{|c|c|c|c|c|}
\hline Firm Perfomance Measure & $\begin{array}{c}\text { AHP } \\
\text { Target } \\
\text { Weight }\end{array}$ & $\begin{array}{l}\text { Qtr } 3 \\
\text { Data } \\
\end{array}$ & $\begin{array}{c}\text { Percent } \\
\text { of } \\
\text { Target }\end{array}$ & $\begin{array}{l}\text { Perf. } \\
\text { Index }\end{array}$ \\
\hline 1. RONA & $5.9 \%$ & $16.0 \%$ & $106.7 \%$ & $6.3 \%$ \\
\hline 2. Sales Growth & $6.3 \%$ & $12.5 \%$ & $104.2 \%$ & $6.6 \%$ \\
\hline 3. WACC & $4.6 \%$ & $13.0 \%$ & $100.0 \%$ & $4.6 \%$ \\
\hline 4. Inventory Turnover & $4.8 \%$ & 18.0 & $109.1 \%$ & $5.2 \%$ \\
\hline 5. Accounts Receivable Days & $4.6 \%$ & 19.0 & $94.4 \%$ & $4.3 \%$ \\
\hline 6. Customer Retention Rate & $8.2 \%$ & $91.0 \%$ & $95.8 \%$ & $7.9 \%$ \\
\hline 7. Sales from New Accounts & $7.3 \%$ & $19.0 \%$ & $95.0 \%$ & $6.9 \%$ \\
\hline 8. Revenue from Value-Added Partnerships & $6.4 \%$ & $29.0 \%$ & $96.7 \%$ & $6.2 \%$ \\
\hline 9. On-time Delivery & $9.8 \%$ & $96.0 \%$ & $101.1 \%$ & $9.9 \%$ \\
\hline 10. Out-of-Stock $(\%)$ & $5.9 \%$ & $2.5 \%$ & $75 . .0 \%$ & $4.4 \%$ \\
\hline 11. Accuracy in Delivery Order $(\%)$ & $7.1 \%$ & $94.0 \%$ & $98.9 \%$ & $7.0 \%$ \\
\hline 12. Pick Efficiency Time & $3.9 \%$ & $97.0 \%$ & $99.0 \%$ & $3.9 \%$ \\
\hline 13. Product Returns $(\%)$ & $5.4 \%$ & $2.0 \%$ & $100.0 \%$ & $5.4 \%$ \\
\hline 14. $\%$ of Revenue from New Products & $4.8 \%$ & $6.1 \%$ & $122.0 \%$ & $5.9 \%$ \\
\hline 15. Employee Training Days & $5.8 \%$ & 10.0 & $100.0 \%$ & $5.8 \%$ \\
\hline 16. Employee Suggestions (\% Increase) & $4.3 \%$ & $5.0 \%$ & $62.5 \%$ & $2.7 \%$ \\
\hline 17. Employee Retention & $4.9 \%$ & $84.0 \%$ & $98.8 \%$ & $4.8 \%$ \\
\hline Performance Index $(\%)$ & $100.0 \%$ & & & $97.8 \%$ \\
\hline
\end{tabular}

The methodology overcomes some of the difficulty managers often have in relating non-financial performance measures to the overall objectives and mission of the firm. A limitation of the research is that this approach has only been used for a family-owned and controlled firm. Future research is needed to assess the implications for different ownership forms. An organization with widely held stock with a substantial institutional ownership might face different performance pressures than a family-owned or family-controlled company. We do not present this methodology as a panacea for every problem in applying value-based management organizations but it is an approach that shows potential for providing a solid platform for sustained growth and profitability.

\section{References}

Banker R. D., Potter, G. and Srinivasan, D. (2000). An empirical investigation of an incentive plan that includes non-financial performance measures. The Accounting Review, January, 65-92.

Dyer (A), J. S. (1990). Remarks on the analytic hierarchy process. Management Science, 36 (3), (March), 249-258. 
Dyer (B), J. S. (1990). A clarification of 'remarks on the analytic hierarchy process'. Management Science, 36 (3), (March), 274-275.

Eccles, R. G. and Pyburn, P. J. (1992). Creating a comprehensive system to measure performance. Management Accounting, October.

Ehrbar, A. (1998). EVA: The real key to creating wealth. New York, NY: John Wiley $\&$ Sons.

Epstein, M. and Manzoni, J. F. (1998). Implementing corporate strategy: From tableaux de bord to balance scorecards. European Management Journal, April, 199-203.

Expert Choice, Inc., Version 2000, Pittsburgh, PA.

Fisher, J. (1992). Use of non-financial performance measures. Journal of Cost Management. (Spring).

Harker, P. T. and Vargas, L. G. (1990). Reply to 'remarks on the analytic hierarchy process' by J. S. Dyer. Management Science, 36 (3), (March), 269-273.

Hawawini, G. and Viallet C. (2002). Finance for executives: Managing for value creation. (2nd Edition). South-Western / Thomson Learning.

Haspeslagh, P., Nada T. and Boulos, F. (2001). Managing for value: It's not just about the numbers. Harvard Business Review, 79 (July-August), 65-73.

Kaplan, R. S. and Norton, D. P. (1992). The balanced scorecard: Measures that drive performance. Harvard Business Review, 70 (Jan-Feb), 71-79.

Ittner, C. D., Larcker, D. F. and Rajan, M. V. (1997). The choice of performance measures in annual bonus contracts. The Accounting Review, April, 223-255.

Liberatore, M. J. \& Miller, T. (1998). A framework for integrating activity-based costing and the balanced scorecard into the logistics strategy development and monitoring process. Journal of Business Logistics, 19 (2), 131- 154.

Liberatore, M. J., Monahan, T. F., \& Tymon, W. G. (1997). A framework for integrating a balanced scorecard to company strategy. Corporate Controller, (Winter), 24-29.

Lynch, R. L. \& Cross, K. F. (1995). Measure up! (2nd Edition). Cambridge, MA: Blackwell Publishers, 47.

Pettit, J. (2000). EVA and strategy. EVAluation, (April), 1-18

Pineno, C. J. (2000). The balanced scorecard: An incremental approach to product lines and distribution. Journal of Contemporary Business Issues, 8 (2), 77-83. 
Saaty, T. L. (1996). The analytic hierarchy process. Pittsburgh, PA: RWS Publications.

Saaty, T. L. (1990). An exposition of the AHP in reply to the paper 'remarks on the analytic hierarchy process'. Management Science, 36 (3), 259-268.

Vargas, L. G. and Zahedi, F. (1993). Special issue on the analytic hierarchy process. Mathematical and Computer Modeling, 17, 4-5.

Wasil, E. A. and Golden, B. L. (1991). Public sector applications of the analytic hierarchy process. Socio-Economic Planning Sciences. 25 (2).

Winkler, R. L. (1990). Decision modeling and rational choice: AHP and utility theory. Management Science, 36 (3), 247-248.

Young, S. D. and O'Byrne, S. F. (2001). EVA and value-based management. New York: McGraw-Hill.

\section{Footnotes}

Name changed to protect the privacy and confidentiality of the organization.

2 It should be noted that an alternative equation is used to calibrate the points for performance measures in which a decrease in the measure's value represents an improvement. The formula is: $200-$ [(current quarter value / target) $x$ 100]. Three of Lavas' measures fall in this category: Accounts Receivable Days, Out-of-Stock, and Product Returns.

Harold D. Fletcher is Professor of Finance at Loyola College in Maryland with over twenty-five years of experience in teaching and consulting. His focus is primarily on the fields of managerial finance and strategic planning. He holds a BS in Accounting from Western Kentucky University, an MA in Economics from the University of Kentucky and a Ph.D. in Finance from the University of Illinois, Champaign-Urbana.

Darlene Brannigan Smith is Associate Professor of Marketing and Academic Director of Graduate Business Programs at Loyola College. She holds a Ph.D. in Marketing from the University of Maryland and an MBA in Finance from the University of Baltimore. Her teaching focus is in the fields of marketing strategy and strategic planning. She is an active consultant focusing primarily in the areas of market planning, needs assessment, and client / customer satisfaction studies. 
